\title{
Antioxidants and Phenolic Secretion in Sugarcane Genotypes Shoots Culture
}

\author{
Ana da Silva Ledo ${ }^{1}$, Maria M. Jenderek ${ }^{2}$, Carlos Alberto da Silva Ledo ${ }^{3} \&$ Tomas Ayala-Silva ${ }^{4}$ \\ ${ }^{1}$ Tissue Plant Culture Laboratory, Embrapa Coastal Tablelands, Aracaju, Sergipe, Brazil \\ ${ }^{2}$ National Laboratory for Genetic Resources Preservation, Plant and Animal Genetic Resources Preservation \\ Unit, USDA-ARS, Fort Collins, CO, USA \\ ${ }^{3}$ Embrapa Cassava \& Fruits, Cruz das Almas, BA, Brazil \\ ${ }^{4}$ National Germplasm Repository, Subtropical Horticulture Research Station, USDA-ARS, Miami, FL, USA \\ Correspondence: Ana da Silva Ledo, Tissue Plant Culture Laboratory, Embrapa Coastal Tablelands, Aracaju, \\ Sergipe CEP 49025-040, Brazil. Tel: 55-79-4009-1362. E-mail: ana.ledo@embrapa.br
}

Received: February 8, $2018 \quad$ Accepted: March 11, $2018 \quad$ Online Published: April 15, 2018

doi:10.5539/jas.v10n5p79 URL: https://doi.org/10.5539/jas.v10n5p79

The research is financed by USDA-ARS CRIS 3012-21000-013-00D and EMBRAPA.

\begin{abstract}
Secretion of phenolic compounds is a major limitation for sugarcane in vitro shoot culture, causing a loss of regenerative capacity and subsequent cell death. In this study, micropropagation and phenolic secretion of four Saccharum genotypes were evaluated in presence of different antioxidants. Aseptic cultures of $S$. officinarum (PI 184794 and PI 88652), S. sinense (PI 29109) and S. robustum (UNK R65P35) were propagated on medium containing antioxidants, citric acid $(100 \mathrm{mg} / \mathrm{L})$, L-cysteine $(100 \mathrm{mg} / \mathrm{L})$, polyvynylpirrolidone $(300 \mathrm{mg} / \mathrm{L})$ and L-glutathione $(50 \mathrm{mg} / \mathrm{L})$ in two consecutive subculture cycles. Interaction between genotypes and antioxidants was significant in both cycles. All genotypes showed good shoot formation, shoot vigor and color, except in PI 88652 which had less shoot development in both the presence and absence of the antioxidants tested. PI 184794 displayed the highest shoot proliferation in the presence of citric acid, and UNK R65P35 produced more shoots per explant in the $2^{\text {nd }}$ subculture. For $S$. sinense (PI 29109), in both subcultures, most shoots were observed in the presence of polyvynylpirrolidone. Medium discoloration due to phenolic secretion was reduced in the presence of citric acid and polyvynylpirrolidone. The type of secreted phenolic compounds differed with genotype as the Principal Component Analysis of cultivation media separated PI 88652 from PI 29109 and UKN R65P35. Phenolic compounds varied in composition and were secreted at various levels as a function of genotype and antioxidant type. Loadings plots indicated the genotype and antioxidant separations were broadly driven by flavonoid compounds.
\end{abstract}

Keywords: flavonoids, genotypic response, micropropagation, Saccharum

\section{Introduction}

The Saccharum genus belongs to the Andropogoneae tribe of the Poaceae (Gramineae) family (Daniels \& Roach, 1987). It is a perennial grass cultivated in tropical and subtropical regions of the world and the global crop production in 2014 was 1900 million metric tons (The Statistics Portal, 2017); in 2013, sugarcane ranked first in commodities (FAO, 2013).

Sugarcane is asexually propagated by stem cuttings or by plants derived by micropropagation (Lal et al., 2015; Michael, 2007). Usually, the cane stems are infected by various pathogens without exhibiting any symptoms (Parmessur et al., 2002), and the propagation rate from field-grown stems is low. In contrast, micropropagation provides a rapid multiplication of healthy sugarcane shoots once aseptic cultures are established. Besides multiplication, in vitro cultures are also used in detection and elimination of sugarcane virus diseases (Snyman et al., 2012) and are a preferred form for conservation of genetic resources, either by preserving shoots in slow growth conditions or by cryopreservation. 
During in vitro organogenesis or somatic embryogenesis, browning of sugarcane culture caused by phenolic secretion can be a major limitation causing a loss of regenerative capacity and subsequent cell death. According to Ndakidemi et al. (2014), the relationship between medium chemical compounds and phenolic exudation influences substantially the intensity of medium discoloration, rooting, explant browning and tissue deterioration. In a culture establishing phase, the phenolic secretion and its oxidation can affect the culture initiation and development (Kerns \& Meyer, 1986; Kumari \& Verma, 2001). Thus the prevention of culture browning is essential in micropropagation of Saccharum plants. Studies conducted by Qin et al. (1997) indicated that sugarcane has a high content of phenolics, and their oxidation is affected by genotypes, the sources of explants and exogenous growth regulators. Similar observations were recorded for Gossypium spp., cotton (Ozyigit et al., 2007) and Strelitzia reginae, bird of paradise (North et al., 2012). Lux-Endrich et al. (2000) suggested that the composition and synthesis of phenolic compounds in plant tissue may be determined by genetic and environmental conditions.

The possibility of controlling phenolic secretion from sugarcane explants by pretreatment with solutions of ascorbic or citric acid, polyvynylpirrolidone (PVP) and cysteine or culturing the explants on medium with these substances, or with activated charcoal has been suggested (Kumari \& Verma, 2001; Lorenzo et al., 2001; Huang et al., 2003; Khan et al., 2007; Lal et al., 2015; Shimelis et al., 2015). However, there is little information on tissue culture responses of various sugarcane species to the type of antioxidants used during culturing and the type of phenolic compounds secreted. Adding from 0.5 to $1 \mathrm{~g} / \mathrm{L} \mathrm{PVP}$ to medium of callus derived sugarcane culture controlled tissue browning but was variety specific (Michael, 2007). Callus derived culture might exhibit somaclonal variation and compromise genetic integrity of propagated material (Nehra et al., 1992; Skrivin et al., 1993; Sahijram et al., 2003; Bairu et al., 2006, 2008, 2011).

The National Plant Germplasm System of the United States Department of Agriculture (USDA) preserves over 400 sugarcane accessions in a clonal form as field plantings. The security backup of the field collection is done by cryopreservation of 0.6-1 mm shoot tips derived from aseptic shoot culture. The shoot cultures are established from apical fragments of field grown canes and it takes usually from 2 to 4 months (genotype dependent; 30-day subculture intervals), after contamination free shoots are obtained, to produce a sufficient number of shoots for cryopreservation. Rooting of the shoot culture is not necessary because the shoots will not be planted before cryopreservation; however, multiplication of a large number of shoots in a short time with a low benzyl aminopurine concentration is desired. Secretion of phenolic compounds and high genotypic variation in the cultivation of tissue culture affects the growth and multiplication of the shoots, and impedes the preservation of the Saccharum genetic resources. Limiting the phenolic occurrence in culture medium might improve shoot multiplication, and limit the number of subcultures needed to produce a large number of shoots, and also it might increase the shoot vigor that supports successful preservation of sugarcane.

The objective of this study was to evaluate in vitro sugarcane shoot performance in the presence of phenolic compounds secreted into medium with selected antioxidants and to characterize the phenolic intensity and composition in the culture medium of three sugarcane species (S. officinarum, S. robustum and S. sinense).

\section{Material and Methods}

\subsection{Plant material and Shoot Cultures}

Apical cane segments of four Saccharum genotypes were obtained from the USDA-ARS, National Germplasm Repository, Miami, FL and established aseptically in vitro at the USDA-ARS PAGRP Unit, Fort Collins, CO ( $S$. officinarum PI 184794 and PI 88652, S. sinense PI 29109 and S. robustum UNK R65P35). After a 10 min sterilization in $70 \%$ isopropyl alcohol (1000033127, Cumberland Swan $\left.{ }^{\circledR}\right)$ followed by $20 \%$ commercial bleach $(6.0 \% \mathrm{NaOCl} ; 20 \mathrm{~min})$, and three rinses in sterile water, the segments were cultured in GA-7 magenta ${ }^{\mathrm{TM}}$ vessels [WxLxH $(77 \times 77 \times 97 \mathrm{~mm})$; V8505, Sigma-Aldrich ${ }^{\circledR}$ ] with $60 \mathrm{~mL}$ of Murashige \& Skoog (1962) propagation medium (MS-519, Sigma-Aldrich ${ }^{\circledR}$ ) with $20 \mathrm{~g} / \mathrm{L}$ sucrose, $0.1 \mathrm{mg} / \mathrm{L}$ kinetin, $0.2 \mathrm{mg} / \mathrm{L}$ use $\mu \mathrm{M}$ for PGR $\mathrm{n}^{6}$-benzyl aminopurine and $8.0 \mathrm{~g} / \mathrm{L}$ of agar (Sigma-Aldrich ${ }^{\circledR} \mathrm{A} 7002$ ) with the $\mathrm{pH}$ adjusted to 5.8, autoclaved for $27 \mathrm{~min}$ at $121{ }^{\circ} \mathrm{C} / 22 \mathrm{psi}$. The cultures were grown in a growth chamber at $25 \pm 2{ }^{\circ} \mathrm{C}$ with a 16 -h photoperiod with 50 $\mathrm{mol} / \mathrm{m}^{2} / \mathrm{s}$ light intensity provided by cool daylight fluorescent lamps (Osram Sylvania, Wilmington, MA). Regenerated shoots were excised and subcultured after 30 days.

\subsection{Micropropagation and Antioxidants}

Excised shoots (from 15 to $20 \mathrm{~mm}$ long), $30 \pm 10$ days old, 9 shoots per box, were transferred to fresh MS propagation medium (as described before) with the following antioxidants individually or in combination: 100

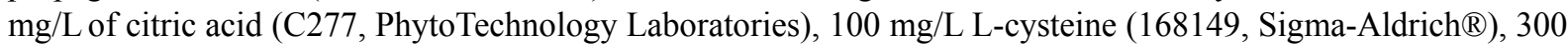
$\mathrm{mg} / \mathrm{L}$ PVP 40,000 (PX 1300, EM Science) and $50 \mathrm{mg} / \mathrm{L}$ L-glutathione (G4251, Sigma-Aldrich ${ }^{\circledR}$ ). The selection 
of the antioxidant type and concentration was based on in-house observations made during micropropagation of other plant species (data not published). After 30 days, cultures were transferred to fresh MS propagation medium with the same antioxidant treatment for another 30 days under same growing conditions, 9 shoots per box and 6 boxes per treatment.

\subsection{Assessment of Micropropagation and Phenolic Secretion}

Genotypic and antioxidant effects were evaluated by observing the number of shoots per explant, their vigor and color, and by assessing the intensity of medium color caused by phenolic secretion during two micropropagation cycles. The two cycles were selected due to previous observations in which the most intense medium discoloration appeared during this time. The shoot vigor was ranked: 1-poor vigor; 2-average good vigor; 3-fully healthy with excellent shoot vigor (adapted from Debnath, 2005). The shoot color was ranked as 1-brown; 2-yellow; 3-light green; 4-dark green and the phenolic secretion intensity (color of medium) was ranked as 1-no phenolic secretion; 2-some; 3-moderate secretion; 4-heavy secretion.

Analysis of secreted phenolic compounds was carried out in propagation media containing antioxidants (1) 100 $\mathrm{mg} / \mathrm{L}$ citric acid; (2) $100 \mathrm{mg} / \mathrm{L}$ L-cysteine; (3) $300 \mathrm{mg} / \mathrm{L} \mathrm{PVP}$; or (4) $50 \mathrm{mg} / \mathrm{L}$ L-glutathione) separately for the three genotypes (PI 88652, PI 29109 and UNK R65P35) at the end of the $1^{\text {st }}$ subculture cycle (30 days after inoculation). The assay of phenolic compounds was performed according to Heuberger et al. (2014), with modifications as noted below.

\subsection{Preparation of Extract}

For metabolite profiling, an approximate $200 \mathrm{mg}$ of culture medium pooled from the culture boxes in each treatment (four media combined with three accessions) was collected by a micropipette and kept in Eppendorf $\mathbb{}$ tubes. The samples were freeze dried and homogenized in a bullet blender. A sequential extraction from $7.5 \mathrm{mg}$ of culture medium was performed, first extracting with $1.0 \mathrm{~mL}$ methanol and secondarily with $1.0 \mathrm{~mL}$ of MTBE/MeOH/Water (6/3/1 v/v/v). The supernatant from each step was collected and pooled. The solvent was evaporated under nitrogen, and the metabolites re-suspended in $100 \mu \mathrm{L}$ methanol and stored at $-80{ }^{\circ} \mathrm{C}$ until further analysis.

\subsection{UPLC-MS Analysis (CSH Phenyl-Hexyl Method)}

The amount of each phenolic compound in each extract was determined by an ultra-performance liquid chromatography mass spectrometry (UPLC-MS) analysis (CSH Phenyl-Hexyl method); $5 \mu \mathrm{L}$ of the methanol extract was injected twice ( $\mathrm{n}=2$ replicates) onto a Acquity UPLC system (Waters Corporation, Milford, MA) in discrete, randomized blocks, and separated using a Acquity UPLC CSH Phenyl-Hexyl column, $1.7 \mu \mathrm{M}, 1.0 \mathrm{x}$ $100 \mathrm{~mm}$ (186005402, Waters $\odot$ ), using a gradient from solvent $\mathrm{A}$ (water, $0.1 \%$ formic acid) to solvent $\mathrm{B}$ (Acetonitrile, $0.1 \%$ formic acid). Calibration was conducted using sodium iodide with $1 \mathrm{ppm}$ mass accuracy. The capillary voltage was held at $2200 \mathrm{~V}$, source temp at $150{ }^{\circ} \mathrm{C}$, and nitrogen de-solvation temperature at $350{ }^{\circ} \mathrm{C}$ with a flow rate of $800 \mathrm{~L} / \mathrm{hr}$.

\subsection{Experimental Design and Statistical Evaluation}

Experimental design to evaluate the effect of the antioxidants and genotypes on the growth and phenolic secretion was fully randomized in a $2 \times 4 \times 5$ factorial scheme $(2$ subculture cycles $\times 4$ genotypes $\times 5$ treatments with or without antioxidants) with six replications per treatment and nine shoots per replication $(\mathrm{n}=54)$. The means were compared by Scott-Knott test at 5\% probability. Pearson's correlation coefficient was calculated to denote the relationship between phenolic secretion and number of shoot/explant, their vigor and color, during the $1^{\text {st }}$ and $2^{\text {nd }}$ subculture cycles. Pearson correlation coefficient for each dependent variable between actual and predicted values was maximized, which is an indicator of the predictive performance of the algorithm. The hypothesis of the correlation coefficient was tested with a two-sided $t$ test. Statistical analyses were performed with the SAS-9.4 program (SAS Institute, 2013).

To explore the metabolome of the culture medium with emphasis on phenolic compound determination, samples from the first experiment were separated for another experiment and a fully randomized $3 \times 4$ factorial scheme ( 3 genotypes $\times 4$ antioxidants) with three replications per treatment was considered. Analysis of variance was carried out for each compound using the Analysis of Variance (AOV) function in R, and p-values were adjusted for false positives using the Bonferroni-Hochberg method in the $\mathrm{p}$ adjust function in R (Benjamini \& Hochberg, 1995). Principal component analysis (PCA) was carried out on mean-centered and Pareto variance-scaled data using the PCA Methods package in R (Stacklies et al., 2007). The results were plotted as a function of retention time and the $-\log$ of the P-value. For all experiments, the differences between the data were considered significant at $5 \%$. 


\section{Results}

\subsection{Effect of Genotypes and Antioxidants on Growth Variables (Shoot Number, Color and Vigor)}

The subculture cycle factor (S) was significant only for the number of shoots/explant and in combination with the genotype $(\mathrm{S} \times \mathrm{G})$ for the shoot vigor (Table 1). The genotype and antioxidants were significant for all the factors and presented very high values. A significant interaction was observed between the evaluated genotypes (G) and the applied antioxidants (A).

The evaluated cultures showed good shoot formation, vigor and color, except the PI 88652 (S. officinarum), which displayed low proliferative capacity and shoot vigor in the presence and the absence of the four antioxidants (Table 2).

S. officinarum (PI 184794) showed a significantly higher number of proliferated shoots in the presence of 100 $\mathrm{mg} / \mathrm{L}$ citric acid (12.53 shoots/explant) and a significantly lower number with $300 \mathrm{mg} / \mathrm{L}$ PVP (8.28 shoots/explant). S. officinarum (PI 88652), S. robustum (UNK R65P35) and S. sinense (PI 29109) showed no significant improvement in shoot number with antioxidants in the medium compared to the control. The antioxidants had no effect on the shoot vigor S. officinarum (PI 88652), S. sinense (PI 29109) and S. robustum (UNK R65P35). However, S. officinarum (PI 184794) had significantly higher vigor with three of the antioxidants compared to PVP and the control.

Table 1. Analysis of variance for number of shoots/explant (NS), shoot color (SC) and shoot vigor (SV) for four Saccharum genotypes

\begin{tabular}{llllllll}
\hline Source of variation & df & MS shoot number & Fr shoot number & MS shoot color & Fr shoot color & MS shoot vigor & Fr shoot vigor \\
\hline Subculture cycle-S & 1 & 6.564 & $5.126^{*}$ & 0.204 & $1.541^{\text {ns }}$ & 0.017 & $0.111^{\text {ns }}$ \\
Genotype-G & 3 & 706.570 & $551.805^{* *}$ & 3.548 & $26.782^{* *}$ & 11.678 & $77.852^{* *}$ \\
Antioxidant-A & 4 & 5.036 & $3.933^{* *}$ & 1.7645 & $13.318^{* *}$ & 0.267 & $1.778^{* *}$ \\
$\mathrm{~S} \times \mathrm{G}$ & 3 & 0.284 & $0.222^{\text {ns }}$ & 0.1819 & $1.373^{\text {ns }}$ & 0.428 & $2.852^{*}$ \\
$\mathrm{~S} \times \mathrm{A}$ & 4 & 0.108 & $0.085^{\text {ns }}$ & 0.0479 & $0.362^{\text {ns }}$ & 0.0167 & $0.111^{\text {ns }}$ \\
$\mathrm{G} \times \mathrm{A}$ & 12 & 12.503 & $9.765^{* *}$ & 1.114 & $8.412^{* *}$ & 0.622 & $4.148^{* *}$ \\
$\mathrm{~S} \times \mathrm{G} \times \mathrm{A}$ & 12 & 0.140 & $0.109^{\text {ns }}$ & 0.081 & $0.613^{\text {ns }}$ & 0.067 & $0.444^{\text {ns }}$ \\
Error & 200 & 1.280 & & 0.132 & & 0.150 & \\
$-\mathrm{VC}(\%)$ & & 12.91 & & 10.54 & & 15.70 & \\
\hline Note. & & & & & \\
\hline
\end{tabular}

Note. ns: not significant; ${ }^{*}$ significant at $5 \%$ by $\mathrm{F}$ test; ${ }^{* *}$ significant at $1 \%$ by $\mathrm{F}$ test; df: degree freedom; ms: mean square; Fr: F ratio; VC: variation coefficient.

Shoot color was significantly better for S. officinarum (PI 184794) and S. robustum (UNK R65P35) with some of the antioxidant treatments while the others were not significantly different. All of the genotypes tested were light green to dark green regardless of the antioxidant added to the culture medium. In general an intensive green color was observed on shoots of all genotypes grown on medium with L-cysteine. 
Table 2. Effect of genotypes and antioxidants (GxA) on the number of shoots/explant, shoot vigor and color of four Saccharum genotypes (means of $1^{\text {st }}$ and $2^{\text {nd }}$ subculture cycles)

\begin{tabular}{|c|c|c|c|c|c|}
\hline Antioxidants & $\begin{array}{l}\text { S. officinarum } \\
\text { PI } 184794\end{array}$ & $\begin{array}{l}\text { S. officinarum } \\
\text { PI } 88652\end{array}$ & $\begin{array}{l}\text { S. sinense } \\
\text { PI } 29109\end{array}$ & $\begin{array}{l}\text { S. robustum } \\
\text { UNK R65P35 }\end{array}$ & Means \\
\hline \multicolumn{6}{|c|}{ Number of shoots/explant } \\
\hline Control & $11.23 \mathrm{aB}$ & $3.71 \mathrm{cA}$ & $10.13 \mathrm{bA}$ & $11.67 \mathrm{aA}$ & 9.18 \\
\hline Citric acid & $12.53 \mathrm{aA}$ & $2.42 \mathrm{~dB}$ & $9.49 \mathrm{cB}$ & $10.77 \mathrm{bB}$ & 8.80 \\
\hline L-cysteine & $10.35 \mathrm{bB}$ & $4.46 \mathrm{cA}$ & $9.73 \mathrm{bB}$ & $11.28 \mathrm{aA}$ & 8.96 \\
\hline PVP & $8.32 \mathrm{bC}$ & $3.68 \mathrm{cA}$ & $10.45 \mathrm{aA}$ & $11.29 \mathrm{aA}$ & 8.44 \\
\hline L-glutathione & $10.37 \mathrm{aB}$ & $4.12 \mathrm{cA}$ & $9.04 \mathrm{bB}$ & $10.26 \mathrm{aB}$ & 8.46 \\
\hline \multicolumn{6}{|l|}{ Shoot vigor } \\
\hline Control & $2.08 \mathrm{bB}$ & $1.92 \mathrm{bA}$ & $2.92 \mathrm{aA}$ & $2.83 \mathrm{aA}$ & 2.44 \\
\hline Citric acid & $2.58 \mathrm{bA}$ & $1.92 \mathrm{cA}$ & $2.58 \mathrm{bA}$ & $3.00 \mathrm{aA}$ & 2.52 \\
\hline L-cysteine & $2.75 \mathrm{aA}$ & $1.75 \mathrm{bA}$ & $2.75 \mathrm{aA}$ & $2.92 \mathrm{aA}$ & 2.54 \\
\hline PVP & $1.92 \mathrm{bB}$ & $1.83 \mathrm{bA}$ & $2.92 \mathrm{aA}$ & $2.75 \mathrm{aA}$ & 2.35 \\
\hline L-glutathione & $2.50 \mathrm{aA}$ & $2.00 \mathrm{bA}$ & $2.83 \mathrm{aA}$ & $2.58 \mathrm{aA}$ & 2.48 \\
\hline \multicolumn{6}{|l|}{ Shoot color } \\
\hline Control & $3.08 \mathrm{cB}$ & $4.00 \mathrm{aA}$ & $3.58 \mathrm{bA}$ & $3.08 \mathrm{cC}$ & 3.44 \\
\hline Citric acid & $3.00 \mathrm{bB}$ & $3.00 \mathrm{bB}$ & $3.25 \mathrm{bB}$ & $3.92 \mathrm{aA}$ & 3.29 \\
\hline L-cysteine & $3.58 \mathrm{bA}$ & $3.92 \mathrm{aA}$ & $3.58 \mathrm{bA}$ & $4.00 \mathrm{aA}$ & 3.77 \\
\hline PVP & $3.00 \mathrm{bB}$ & $3.75 \mathrm{aA}$ & $3.50 \mathrm{aA}$ & $3.58 \mathrm{aB}$ & 3.46 \\
\hline L-glutathione & $3.00 \mathrm{bB}$ & $3.83 \mathrm{aA}$ & $3.17 \mathrm{bB}$ & $3.25 \mathrm{bC}$ & 3.31 \\
\hline
\end{tabular}

Note. Means followed by the same lowercase letter (rows) and the same uppercase letter (columns) are not different from each other according to Scott-Knott test at 5\% probability.

${ }^{1}$ Shoot vigor rank: 1-poor vigor; 2-average good vigor; 3-fully healthy with excellent shoot vigor; 4-heavy secretion; ${ }^{2}$ Shoot color rank: 1-brown; 2-yellow; 3-light-green; 4-dark green.

In all genotypes, the most shoots/explant was observed in the second subculture cycle (Table 3). The GxV interaction was indicated by the high shoot vigor maintained in S. sinense (PI 29109) and S. robustum (UNK R65P35) in the second subculture.

Table 3. Effect of subculture cycle on the number of shoots/explant and the shoot vigor of four Saccharum genotypes

\begin{tabular}{llllll}
\hline Subculture Cycle & $\begin{array}{l}\text { S. officinarum } \\
\text { PI 184794 }\end{array}$ & $\begin{array}{l}\text { S. officinarum } \\
\text { PI 88652 }\end{array}$ & $\begin{array}{l}\text { S. sinense } \\
\text { PI 29109 }\end{array}$ & $\begin{array}{l}\text { S. robustum } \\
\text { UNK R65P35 }\end{array}$ & Means \\
\hline $\begin{array}{l}\text { Number of shoots/explant } \\
1^{\text {st }} \text { subculture }\end{array}$ & 10.41 & 3.51 & 9.51 & 10.96 & $8.60 \mathrm{~B}$ \\
$2^{\text {nd }}$ subculture & 10.71 & 3.84 & 10.03 & 11.15 & $8.93 \mathrm{~A}$ \\
\hline $\begin{array}{l}\text { Shoot } \text { vigor } \\
1^{\text {st }} \text { subculture }\end{array}$ & $2.30 \mathrm{bA}$ & $2.00 \mathrm{cA}$ & $2.77 \mathrm{aA}$ & $2.77 \mathrm{aA}$ & 2.46 \\
$2^{\text {nd }}$ subculture & $2.43 \mathrm{bA}$ & $1.77 \mathrm{cB}$ & $2.83 \mathrm{aA}$ & $2.87 \mathrm{aA}$ & 2.48 \\
\hline
\end{tabular}

Note. Means followed by the same lowercase letter (rows) and the same uppercase letter (columns) are not different from each other according to Scott-Knott test at $5 \%$ probability.

${ }^{1}$ Shoot vigor rank: 1-poor vigor; 2-average good vigor; 3-fully healthy with excellent shoot vigor.

\subsection{Phenolic Secretion and Correlation With Growth Variables}

All the factors and interactions were significant for phenolic secretion (Table 4). Phenolic secretion into the medium and its intensity (measured by the medium discoloration) was significant for the genotype $\times$ antioxidant $\times$ subculture interaction. 
Table 4. Analysis of variance for phenolic color rank in medium with shoot cultures of four Saccharum species

\begin{tabular}{llll}
\hline Source of variation & $\mathrm{df}$ & $\mathrm{ms}$ & $\mathrm{Fr}$ \\
\hline Subculture cycle-S & 1 & 0.600 & $3.529^{\mathrm{ns}}$ \\
Genotype-G & 3 & 9.6778 & $56.928^{* *}$ \\
Antioxidant-A & 4 & 2.598 & $15.282^{* *}$ \\
$\mathrm{~S} \times \mathrm{G}$ & 3 & 1.167 & $6.863^{* *}$ \\
$\mathrm{~S} \times \mathrm{A}$ & 4 & 1.402 & $8.248^{* *}$ \\
$\mathrm{G} \times \mathrm{A}$ & 12 & 1.125 & $6.622^{* *}$ \\
$\mathrm{~S} \times \mathrm{G} \times \mathrm{A}$ & 12 & 0.580 & $3.411^{* *}$ \\
Error & 200 & 0.170 & \\
\hline $\mathrm{VC}$ & & & \\
\hline
\end{tabular}

Note. ns: not significant; ${ }^{*}$ significant at $5 \%$ by $\mathrm{F}$ test; ${ }^{* *}$ significant at $1 \%$ by $\mathrm{F}$ test; df: degree freedom; ms: mean square ; Fr: F ratio; VC: variation coefficient.

Variations in the medium color intensity due to phenolic secretion were observed in both cycles for all genotypes (Table 5). In the $1^{\text {st }}$ subculture cycle the genotypes showed different phenolic intensity. S. officinarum (PI 184794) and S. robustum (UNK R65P35) presented lowest phenolic secretion in the presence of PVP $(2.50 ; 2.50$, respectively). The activated charcoal (AC) induced the lowest discoloration of medium for S. robustum (UNK R65P35). No difference in medium discoloration between the applied antioxidants was observed in S. sinense (PI 29109) culture media.

Table 5. Effect of antioxidants (A) and subculture cycles (S) on the phenolic secretion ${ }^{1}$ in cultures of four Saccharum spp. genotypes

\begin{tabular}{|c|c|c|c|c|c|c|c|c|c|}
\hline \multirow[t]{2}{*}{ Antioxidants } & \multicolumn{2}{|c|}{$\begin{array}{l}\text { S. officinarum } \\
\text { PI } 184794\end{array}$} & \multicolumn{2}{|c|}{$\begin{array}{l}\text { S. officinarum } \\
\text { PI } 88652\end{array}$} & \multicolumn{2}{|c|}{$\begin{array}{c}\text { S. sinense } \\
\text { PI } 29109\end{array}$} & \multicolumn{2}{|c|}{$\begin{array}{c}\text { S. robustum } \\
\text { UNK R65P35 }\end{array}$} & \multirow[t]{2}{*}{ Means } \\
\hline & $1^{\text {st }} \mathrm{SC}$ & $2^{\text {nd }} \mathrm{SC}$ & $1^{\text {st }} \mathrm{SC}$ & $2^{\text {nd }} \mathrm{SC}$ & $1^{\text {st }} \mathrm{SC}$ & $2^{\text {nd }} \mathrm{SC}$ & $1^{\text {st }} \mathrm{SC}$ & $2^{\text {nd }} \mathrm{SC}$ & \\
\hline Control & $2.67 \mathrm{a}$ & $3.00 \mathrm{a}$ & $4.00 \mathrm{a}$ & $4.00 \mathrm{a}$ & $2.83 b$ & $3.67 \mathrm{a}$ & $4.00 \mathrm{a}$ & $4.00 \mathrm{a}$ & $3.52 \mathrm{~A}$ \\
\hline $\mathrm{AC}$ & $2.83 \mathrm{a}$ & $3.00 \mathrm{a}$ & $4.00 \mathrm{a}$ & $3.67 \mathrm{a}$ & $3.17 \mathrm{~b}$ & $3.67 \mathrm{a}$ & $3.00 \mathrm{~b}$ & $3.50 \mathrm{a}$ & $3.35 \mathrm{~B}$ \\
\hline L-CYS & $3.33 \mathrm{a}$ & $2.00 \mathrm{~b}$ & $4.00 \mathrm{a}$ & $4.00 \mathrm{a}$ & $4.00 \mathrm{a}$ & $4.00 \mathrm{a}$ & $4.00 \mathrm{a}$ & $4.00 \mathrm{a}$ & $3.67 \mathrm{~A}$ \\
\hline PVP & $2.50 \mathrm{~b}$ & $3.00 \mathrm{a}$ & $3.00 \mathrm{a}$ & $3.33 \mathrm{a}$ & $3.17 \mathrm{a}$ & $3.50 \mathrm{a}$ & $2.50 \mathrm{~b}$ & $3.33 \mathrm{a}$ & $3.04 \mathrm{C}$ \\
\hline L-GLUT & $3.50 \mathrm{a}$ & $2.50 \mathrm{~b}$ & $3.67 \mathrm{a}$ & $3.83 \mathrm{a}$ & $3.17 \mathrm{a}$ & $3.00 \mathrm{a}$ & $3.67 \mathrm{a}$ & $4.00 \mathrm{a}$ & $3.42 \mathrm{~B}$ \\
\hline S Means & $2.97 \mathrm{a}$ & $2.70 \mathrm{~b}$ & $3.73 \mathrm{a}$ & $3.77 \mathrm{a}$ & $3.27 \mathrm{~b}$ & $3.57 \mathrm{a}$ & $3.43 \mathrm{~b}$ & $3.77 \mathrm{a}$ & $3.42 \mathrm{~B}$ \\
\hline G Means & $2.83 \mathrm{c}$ & & $3.75 \mathrm{a}$ & & $3.42 \mathrm{~b}$ & & $3.60 \mathrm{a}$ & & \\
\hline
\end{tabular}

Note. Means followed by the same lowercase letter (rows) and the same uppercase letter (columns) are not different from each other according to Scott-Knott test at $5 \%$ probability.

${ }^{1}$ Phenolic secretion rank: 1-no phenolic secretion; 2-some; 3-moderate secretion. AC: ascorbic acid; L-CYS: L-cysteine; PVP: polyvinylpyrrolidone; L-GLUT: L-glutathione.

Except in PI 184794, all other genotypes in the $2^{\text {nd }}$ subculture cycle did not show any effect of the antioxidants on the medium discoloration. PI 184794 showed the lowest phenolic rank in the presence of L-cysteine (2.00) and L-glutathione (2.50). Antioxidants did not present effect on phenolic rank in both subcultures for PI 88652.

For S. sinense (PI 29109) and S. robustum (UNK R65P35), the average ranking for culture medium discoloration due to phenolic secretion seemed to be slightly higher in the $2^{\text {nd }}$ subculture than in the $1^{\text {st }}$ one. The expectation was to observe less phenolic secretion with each subsequent subculture, as it was observed for S. officinarum (PI 184794). However, an increase in phenolic secretion in in vitro cultivation of other sugarcane genotypes was noticed, even in the $4^{\text {th }}$ and $5^{\text {th }}$ subculture (data not shown).

In both subculture cycles, the intensity of medium color caused by phenolic secretion was negatively correlated with the number of shoots/explant $(-0.2520 ;-0.2391$, respectively, $p<0.01)$ (Table 6). Negative correlation indicated an inhibitory effect of phenolic compounds on in vitro shoot proliferation. Correlation between phenolic secretion and shoot vigor was not significant in either cycle $(p>0.05)$; however, in the $2^{\text {nd }}$ subculture, a 
positive correlation between phenolic secretion and shoot color $(0.3148, \mathrm{p}<0.01)$, and shoot vigor with the number of shoots/explant $(0.6121, \mathrm{p}<0.01)$ was observed.

Table 6. Bivariate Pearson's correlations among medium color due to phenolic secretion, shoot number, shoot color and shoot vigor, during the $1^{\text {st }}$ and $2^{\text {nd }}$ subculture cycles of Saccharum genotypes

\begin{tabular}{llll}
\hline & Phenolic secretion & Shoot color & Shoot vigor \\
\hline$I^{\text {st }}$ subculture & & & \\
Number of shoots/explant & $-0.2520^{* *}$ & $-0.1467^{\mathrm{ns}}$ & $0.4557^{* *}$ \\
Phenolic secretion & & $0.1527^{\mathrm{ns}}$ & $0.0179^{\mathrm{ns}}$ \\
Shoot color & & $0.1187^{\mathrm{ns}}$ \\
$2^{\text {nd }}$ subculture & $-0.2391^{* *}$ & $-0.2089^{*}$ & $0.6121^{* *}$ \\
Number of shoots/explant & & $0.3148^{* *}$ & $-0.0797^{\mathrm{ns}}$ \\
Phenolic secretion & & & $-0.0427^{\mathrm{ns}}$ \\
Shoot color & &
\end{tabular}

Note. ns: not significant; * significant at $5 \%$ by t test; $* *$ significant at $1 \%$ by $\mathrm{t}$ test.

\subsection{Effect of Antioxidants and Genotypes on the Secreted Phenolic Compounds}

Based on the UPLC-MS data analysis, the Principal Component (PC) 2 and PC3 collectivity offered the best separation of the three genotypes based on the phenolics secreted into the culture medium (Figure 1A). PC3, in particular, offered separation of PI 88652 from the other two genotypes. The PC loadings plot (Figure 1B) indicated that this separation was largely driven by flavonoid compounds, as dihydroxyflavone, dihydroxy-methoxyflavone and 5,6-dihydroxy-7-methoxyflavone which accumulated in this genotype.
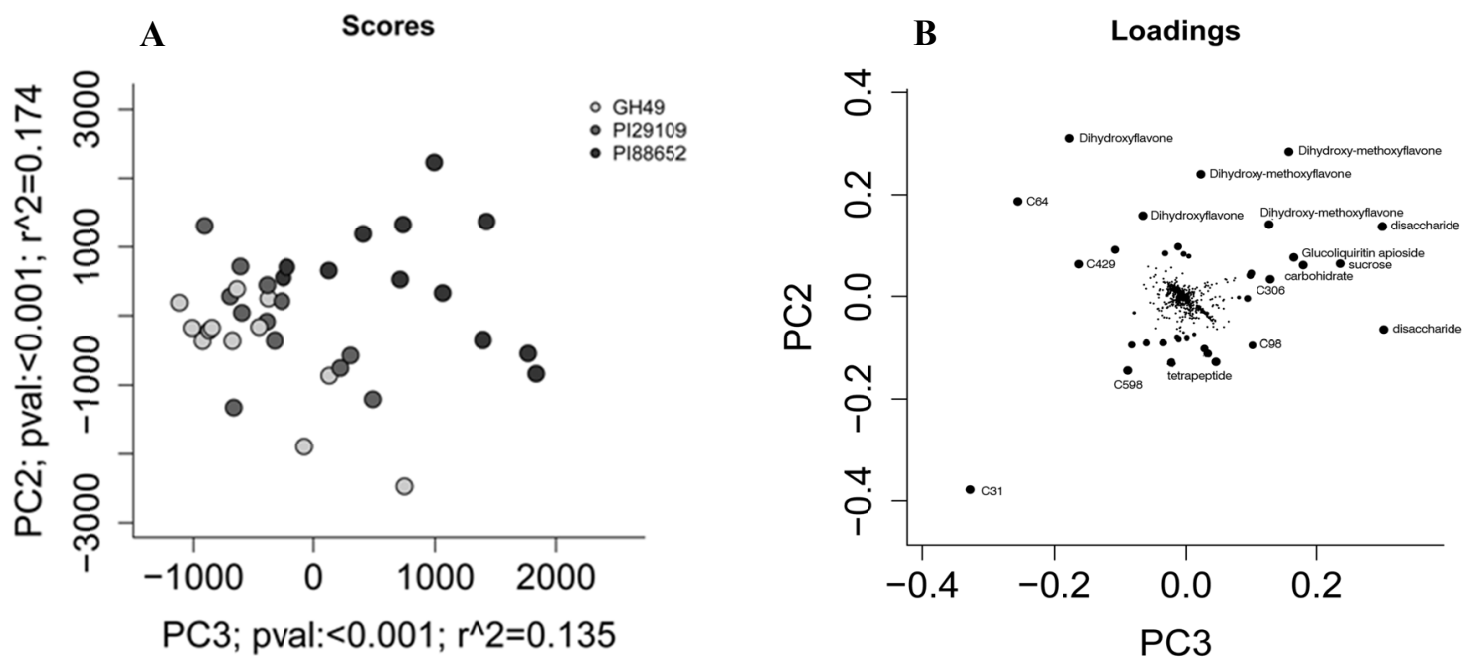

Figure 1. A-Principal Component (PC) variation plots of phenolic compounds secreted into culture media cultivated with three Saccharum genotypes (PI 88652, PI 29109 and UNK R65P35) by UPLC-MS; B-PC loading plots of phenolic compounds show correlations between different Saccharum genotypes

The same two PCAs groups (PC2 and PC3) separated phenolic compounds present in the medium with the antioxidants; in the separation, treatment with PVP $(300 \mathrm{mg} / \mathrm{L})$ was distinguishable (Figure 2A, group 3) from the three other antioxidants (citric acid, L-cysteine, and L-glutathione) that were largely driven by flavonoid compounds (Figure 2B).

According to ANOVA, the flavonoid compounds had different abundance responses as a function of the genotypes and antioxidants (Figure 3). The genotype and antioxidant type had a significant effect at the dihydroxy-methoxyflavone, dihydroxyflavone-rhamnoside and hydroxyl-methoxyflavone abundances. PI 88652 in the presence of all antioxidants, except $300 \mathrm{mg} / \mathrm{L}$ PVP, presented higher dihydroxy-methoxyflavone 
abundance than UNK R65P35 and PI 29109. UNK R65P35, in the presence of $50 \mathrm{mg} / \mathrm{L}$ L-glutathione, showed a higher dihydroxyflavone-rhamnoside and hydroxyl-methoxyflavone presence than PI 29109 and PI 88652.

A

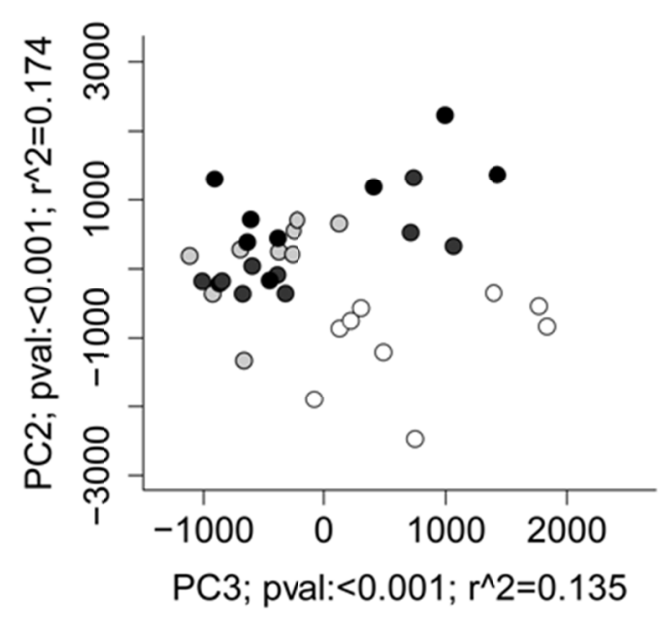

B

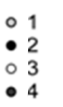

Figure 2. A-Principal Component (PC) variation plots of phenolic compounds secreted into culture media supplemented with four antioxidants (1-100 mg/L citric acid; 2-100 mg/L L-cysteine; 3-300 mg/L PVP and 4-50 $\mathrm{mg} / \mathrm{L}$ L-glutathione) by UPLC-MS; B-PC loading plots of phenolic compounds show correlations between different antioxidants

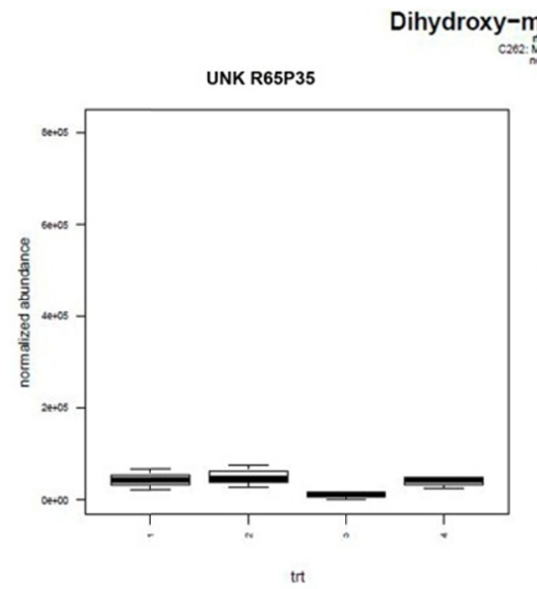

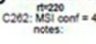
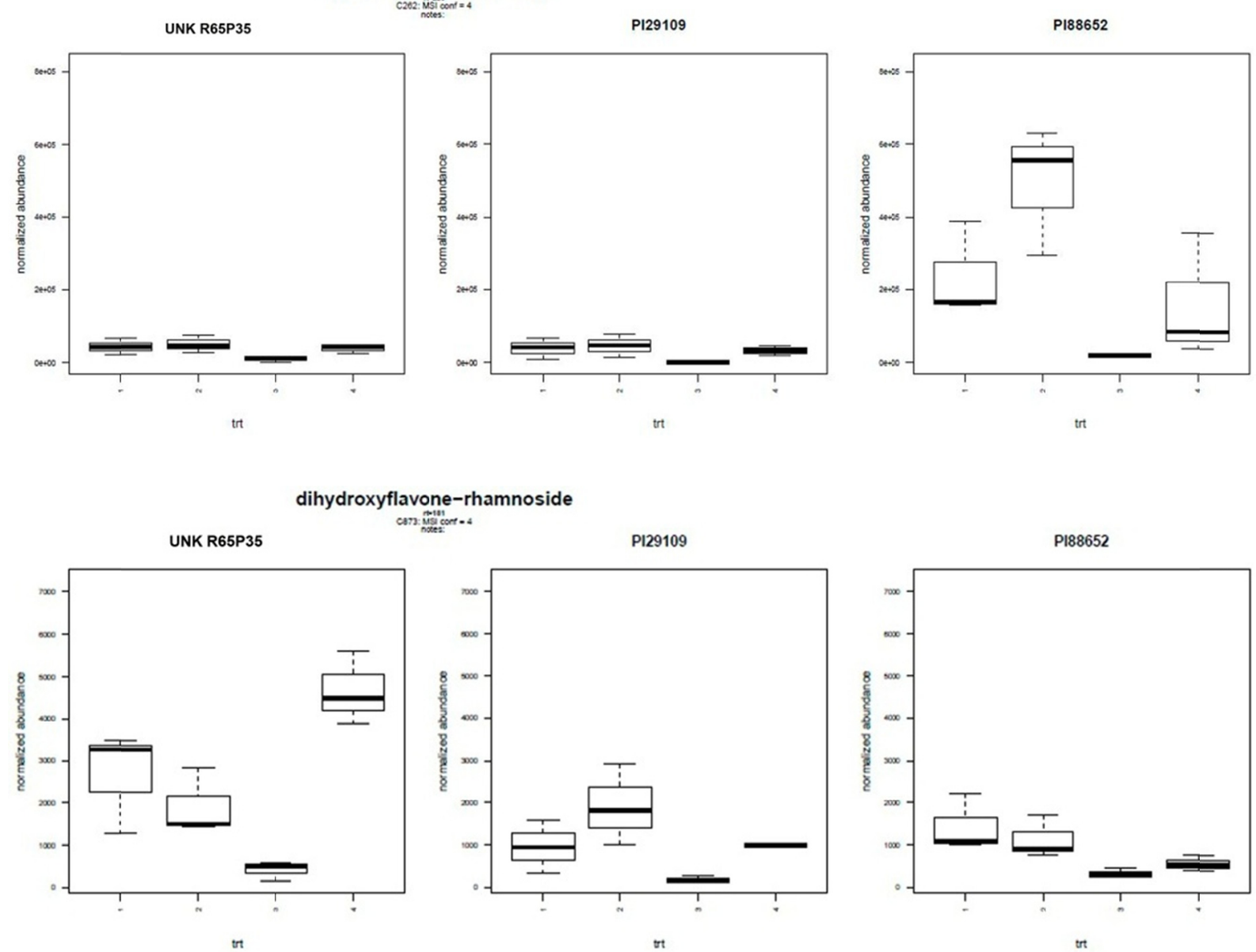

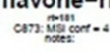

$$
\text { natcoted }
$$

P129109

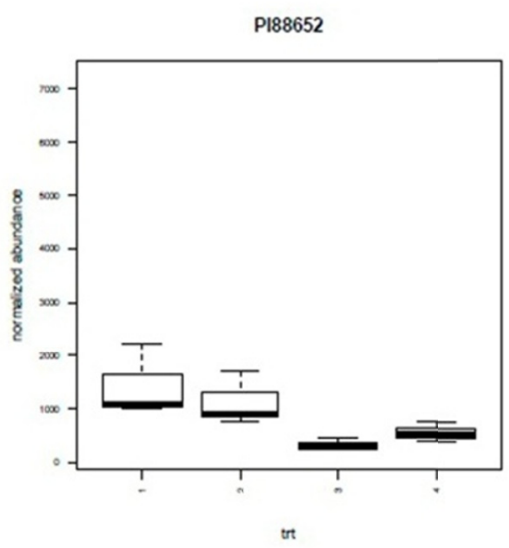




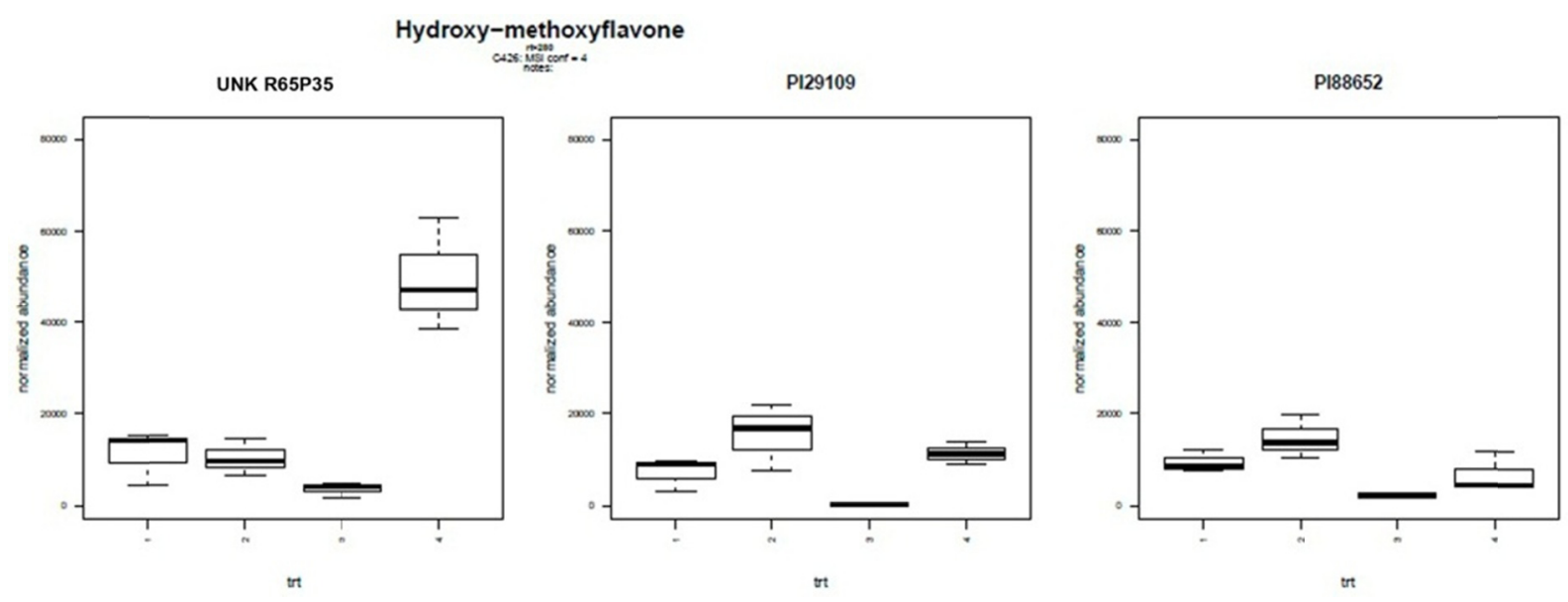

Figure 3. Relative quantification of some flavonoids (normalized abundance) as a function of genotypes and antioxidants (1-100 mg/L citric acid; 2-100 mg/L L-cysteine; 3-300 mg/L PVP and 4-50 mg/L L-glutathione)

\section{Discussion}

Pretreatment of sugarcane explants using solutions of ascorbic acid, citric acid, PVP and cysteine or culturing the explants on medium with the substances or activated charcoal was reported by several authors (Kumari \& Verma, 2001; Lorenzo et al., 2001; Huang et al., 2003; Khan et al., 2007; Michael, 2007; Lal et al., 2015; Shimelis et al., 2015). Studies on in vitro shoot proliferation in the presence of antioxidants and their control of phenolic secretion are sparse and predominantly pertain to $S$. officinarum. In the present research, beyond the $S$. officinarum accessions, we studied $S$. robustum and $S$. sinense shoot cultures and genotype specific responses to the antioxidant types were observed.

The results of this study underlined the significant interaction between genotypes and antioxidants during in vitro cultivation of sugarcane. The higher shoot proliferation of the PI 184794 (S. officinarum) in the presence of 100 $\mathrm{mg} / \mathrm{L}$ citric acid and lower at $300 \mathrm{mg} / \mathrm{L}$ PVP than without the antioxidants, contrasts with the results reported by Huang et al. (2003); Michael (2007) and Shimelis et al. (2015). Huang et al. (2003) observed that PVP reduced shoot browning in GT11 and ROC16 sugarcane varieties (S. officinarum) and Shimelis et al. (2015) in C86-12 (S. officinarum) at $300 \mathrm{mg} / \mathrm{L}$ PVP. According Michael (2007), an addition from 500 to $1000 \mathrm{mg} / \mathrm{L}$ of PVP in medium for cultivation of callus derived culture in constant darkness lessened tissue browning. In the present experiment, discoloration (due to phenolic secretion) of medium with $300 \mathrm{mg} / \mathrm{L}$ PVP showed the lowest average color intensity. However, both $S$. officinarum accessions produced a significantly fewer shoots on medium with PVP. The unexpected behavior in regard to shoot number and vigor of $S$. officinarum in the presence of PVP might be due to the genotypic makeup of the accessions and the in vitro regeneration path applied. In this study, the quantity of citric acid incorporated in the medium probably moderately reduced the leaching of the phenolic compounds and supported a healthy morphogenetic response in S. officinarum (PI 184794). On the other hand, the S. robustum (UNK R65P35) and S. sinense (PI 29109) showed a larger number of shoots per explant in the presence of PVP but a similar number of shoots was observed in the absence of antioxidant (control).

Significant differences between the three sugarcane species in the abundance of flavonoids secreted into cultivation medium were observed. Fewer shoots per explant induced in S. officinarum (PI 88652), in the presence and absence of all antioxidants in both subculture cycles, was most likely due to the moderate and heavy phenolic secretion observed for the genotype, in combination with the high abundance of flavonoids present in the medium, as dihydroxy-methoxyflavone, and a low genetic capacity of the accession to produce shoots. An inhibitory effect of flavonoids, such as tephroleocarpin, glabranin, and methylglabranin isolated from the Tephrosia species, on some photosynthesis phases, was described by Céspedes et al. (2001). Recently, this repressive effect was reported in photosynthetic electron transport chain and in vivo during germination and growth of Physalis ixocarpa, Trifolium alexandrinum and Lolium perenne plants (Morales-Flores et al., 2015). Genes involved in isoflavone biosynthesis were identified in sugarcane (Franca et al., 2001). Colombo et al. (2006) described a high content of flavonoids found in sugarcane juice and its by-products (bagasse and leaves) 
in comparison to other flavonoid sources. Despite the high levels of dihydroxyflavone-rhamnoside and hydroxyl-methoxyflavone, S. robustum (UNK R65P35) showed good shoot proliferation.

Another observation pertains to the variation in genotypic responses between the two subculture cycles in shoot vigor and phenolic secretion. In PI 184794, during the $1^{\text {st }}$ cycle, phenolic secretion was higher than in the $2^{\text {nd }}$ cycle in the presence of L-cysteine and L-glutathione, disagreeing with Lorenzo et al. (2001) that observed an increase of phenol compounds in sugarcane cultivar C-1051-73 when the culture medium was changed. This might be a genotype specific reaction of S. officinarum (PI 184794) considering that $S$. sinense (PI 29109) and $S$. robustum (UNK R65P35) had the lowest phenolic ranks on the $2^{\text {nd }}$ subculture cycle. The make-up and synthesis of phenolics in plant tissue may be determined by genetics and environmental conditions (Lux-Endrich et al., 2000). The results of this study agree with Rodrigues et al. (2011) and Kala et al. (2012), who observed that Saccharum sp. and Psidium sp. genotypes showed variation in secretion of phenolic compounds. Genotype dependence of the in vitro organogenesis responses was also reported by Gandonou et al. (2005) for nine sugarcane (Saccharum sp.) commercial cultivars. Another aspect to consider is the relation between auxin metabolism and phenolic secretion (Lorenzo et al., 2001). In studies on the effect of phenolic acids and their derivatives upon the growth of Avena sativa L. coleoptiles, Wolf et al. (1976) reported different effects of phenolic compounds on the plant growth and inhibition in the presence of indole acetic acid oxidation.

Based on Pearson's correlation coefficient, in both subculture cycles the number of shoots/explant was negatively correlated with phenolic secretion. Kerns and Myer Jr. (1986) emphasized the phenolic secretion and other exudate discharge observed during explant initiation into tissue culture systems lessened with growth and development. However, controversial opinions have been published on the relation between cell and tissue proliferation and low intensity of phenolics found in different species as Medicago sativa L. (Cvikrová et al., 1996), Nicotiana tabacum L. (Chirek, 1990) and Pinus sp. (Herman, 1991). Lorenzo et al. (2001) showed that the increase of phenolic content during the first three days of sugarcane culture is due to the most intensive cell division period, but later the secretion decreased.

The separation by principal components suggests that phenolic compounds, as flavonoids, are secreted at different levels as a function of the genotype and antioxidant. These aspects were observed by other authors for cotton (Ozyigit et al., 2007) and Hawk tea (Tan et al., 2016). These results suggest that additional antioxidant types, not included in this research, might be effective in controlling phenolic secretion in diverse Saccharum genotypes.

\section{Conclusions}

The research reinforced the strong interaction between Saccharum genotypes and phenolic secretion into in vitro shoot culture medium. The studies demonstrated that including citric acid $(100 \mathrm{mg} / \mathrm{L}$ S. officinarum PI 184794) or PVP $(300 \mathrm{mg} / \mathrm{L} S$. robustum UNK R65P35 and S. sinense PI 29109) in culture medium reduced the medium discoloration caused by the phenolic secretion. The number of shoots was negatively correlated with the phenolic secretion; hence, antioxidants might promote shoot development. The high levels of flavonoids secretion by S. officinarum PI 88652 had an adverse effect on in vitro shoot development and the culture vigor. The ability of $S$. officinarum and $S$. robustum in vitro cultures to produce flavonoid compounds in the presence of antioxidants might be a desired characteristic in producing flavonoids on a larger scale throughout the year under controlled environmental conditions.

\section{References}

Bairu, M. W., Aremu, A. O., \& van Staden, J. (2011). Somaclonal variation in plants: Causes and detection methods. Plant Growth Regulators, 63, 147-173. https://doi.org/10.1007/s10725-010-9554-x

Bairu, M. W., Fennel, C. W., \& van Staden, J. (2006). The effect of plant growth regulators on somaclonal variation in Cavendish banana (Musa AAA cv. 'Zelg'). Scientia Horticulturae, 108, 347-351. https://doi.org/10.1016/j.scienta.2006.01.039

Bairu, M. W., Strik, W. A., Doležal, K., \& van Staden, J. (2008). The role of topolins in micropropagation and somaclonal variation of banana cultivars 'Williams' and 'Grand Naine' (Musa spp. AAA). Plant Cell Tissue Organ Culture, 95, 373-379. https://doi.org/10.1007/s11240-008-9451-4

Benjamini, Y., \& Hochberg, Y. (1995). Controlling the false discovery rate-A practical and powerful approach to multiple testing. Journal of the Royal Statistical Society. Series B. Statistical Methodology, 57(1), 289-300. Retrieved from http://www.jstor.org/stable/2346101

Céspedes, C. L., Achnine, L., Lotina-Hennsen, B., Salazar, J. R., Gómez-Garibay, F., \& Calderón, J. S. (2001). Inhibition of photophosphorylation and electron transport by flavonoids and biflavonoids from endemic 
Tephrosia spp. of Mexico. Pesticide Biochemistry and Physiology, 69, 63-76. https://doi.org/10.1006/ pest. 2000.2522

Chirek, Z. (1990). Changes in the content of phenolic compounds and IAA-oxidase activity during the growth of tobacco crown gall suspension culture. Biologia Plantarum, 32, 19-27. https://doi.org/10.1007/BF02897338

Colombo, R., Lancas, F. M., \& Yariwake, J. H. (2006). Determination of flavonoids in cultivated sugarcane leaves, bagasse, juice and in transgenic sugarcane by liquid chromatography-UV detection. Journal of Chromatography A, 1103(1), 118-24. https://doi.org/10.1016/j.chroma.2005.11.007

Cvikrová, M., Hrubcova, M., Eder, J., \& Binarova, P. (1996). Changes in the levels of endogenous phenolics, aromatic monoamines, phenylala-nine ammonia-lyase, peroxidase and auxin oxidase activities during initiation of alfalfa embryogenic and non-embryogenic calli. Plant Physiology and Biochemistry, 34, 853-861. Retrieved from http://agris.fao.org/agris-search/search.do?recordID=FR9701591

Daniels, J., \& Roach, B. (1987). Taxonomy and evolution. In D. J. Heinz (Ed.), Sugarcane improvement through breeding (pp. 7-89). Elsiever, New York. https://doi.org/10.1016/B978-0-444-42769-4.50007-2

Debnath, S. C. (2005). Effects of carbon source and concentration on development of lingonberry (Vaccinium vitis-idaea L.) shoots cultivated in vitro from nodal explants. In Vitro Cellular \& Developmental Biology_Plant, 41, 145-150. https://doi.org/10.1079/IVP2004590

FAO. (2013) Value of Agricultural Production, Sugarcane. Retrieved June 2, 2017, from http://faostat3.fao.org/ browse/rankings/commodities_by_regions/E

Franca, S. C., Roberto, P. G., Marins, M. A., Puga, R. D., Rodrigues, A., \& Pereira, J. O. (2001). Biosynthesis of secondary metabolites in sugarcane. Genetics and Molecular Biology, 24, 243-50. https://doi.org/10.1590/ S1415-47572001000100032

Gandonou, C., Errabii, T., Abrini, J., Idaomar, M., Chibi, F., \& Skali-Senhaji, N. (2005). Effect of genotype on callus induction and plant regeneration from leaf explants of sugarcane (Saccharum sp.). African Journal of Biotechnology, 4(11), 1250-1255. https://doi.org/10.5897/AJB2005.000-3248

Heuberger, A. L., Broeckling, C. D., Kirkpatrick, K. R., \& Prenni, J. E. (2014). Application of nontargeted metabolite profiling to discover novel markers of quality traits in an advanced population of malting barley. Plant of Biotechnology Journal, 12(2), 147-160. https://doi.org/10.1111/pbi.12122

Huang, C. M., Li, Y. R., \& Ye, Y. P. (2003). Minimizing phenol pollution in sugarcane stem apical meristem culture. Sugar Tech Journal, 5, 297-300. https://doi.org/10.1007/BF02942489

Kala, S., Sharma, S., \& Kajla, S. (2012). Effect of antioxidants on in vitro exudation of phenolic compounds and regeneration in cultured explants of guava rootstocks. Indian Journal of Horticulture, 2, 05-08.

Kerns, H. R., \& Meyer Jr, M. M. (1986). Tissue culture propagation of Acer freemanii using thidiazuron to stimulate shoot tip proliferation. HortScience, 21, 1209-1210.

Khan, S. A., Rashid, H., Chaudhary, M. F., \& Chaudhry, Z. (2007). Optimization of explant sterilization condition in sugarcane cultivars. Pakistan Journal of Agricultural Research, 20, 119-123.

Kumari, R., \& Verma, D. K. (2001). Development of micropropagation protocol for sugarcane (Saccharum officinarum L.) - A review. Agricultural Reviews, 22, 87-94. Retrieved from http://www.arccjournals.com/ uploads/articles/ar222003.pdf

Lal, M., Tiwari, A. K., Gupta, G. N., \& Kavita, K. (2015). Commercial scale micropropagation of sugarcane: constraints and remedies. Sugar Tech, 17, 339-347. https://doi.org/10.1007/s12355-014-0345-y

Lorenzo, J. C., Angeles, M. L., Pelaez, O., Gonzalez, A., Cid, M., Iglesias, A., ... Borroto, C. (2001). Sugarcane micropropagation and phenolic excretion. Plant Cell Tissue Organ Culture, 65, 1-8. https://doi.org/10.1023/ A:1010666115337

Lux-Endrich, A., Treautter, D., \& Feucht, W. (2000). Influence of nutrients and carbohydrate supply on the phenol composition of apple shoot cultures. Plant Cell Tissue Organ Culture, 60, 15-21. https://doi.org/ 10.1023/A:1006406527242

Michael, P. S. (2007). Micropropagation of elite sugarcane planting materials from callus culture in vitro. Journal and Proceedings of the Royal Society of New South Wales, 140, 79-86. Retrieved from https://www.researchgate.net/publication/274139355_Micropropagation_of_elite_sugarcane_planting_mate rials_from_callus_culture_in_vitro?tab $=$ overview 
Morales-Flores, F., Olivares-Palomares, K. S., Aguilar-Laurents, M. I., Rivero-Cruz, J. F., Lotina-Hennsen, B., \& King-Díaz, B. (2015). Flavonoids affect the light reaction of photosynthesis in vitro and in vivo as well as the growth of plants. Journal of Agricultural and Food Chemistry, 63, 8106-8115 https://doi.org/10.1021/ acs.jafc.5b02842

Murashige, T., \& Skoog, F. (1962). A revised method for rapid growth and bioassays with tobacco tissue cultures. Physiologia Plantarum, 15, 473-497. https://doi.org/10.1111/j.1399-3054.1962.tb08052.x

Ndakidemi, C., Mneney, E., \& Ndakidemi, P. (2014). Effects of ascorbic acid in controlling lethal browning in in vitro culture of Brahylaena huillensis using nodal segments. American Journal of Plant Sciences, 5, 187-191. https://doi.org/10.4236/ajps.2014.51024

Nehra, N. S., Katha, K. K., Stushnoff, C., \& Glies, K. L. (1992). The influence of plant growth regulator concentrations and callus age on somaclonal variation in callus culture regenerants of strawberry. Plant Cell Tissue Organ Culture, 29, 257-268. https://doi.org/10.1007/BF00034361

North, J. J., Ndakidemi, P. A., \& Laubscher, C. P. (2012). Effects of antioxidants, plant growth regulators and wounding on phenolic compound excretion during micropropagation of Strelitzia reginae. International Journal of Physical Sciences, 7(4), 638-646. https://doi.org/10.5897/IJPS11.786

Ozyigit, II, Kahraman, M. V., \& Ercan, O. (2007). Relation between explant age, total phenols and regeneration response in tissue cultured cotton (Gossypium hirsutum L.). African Journal of Biotechnology, 6(1), 3-9. Retrieved from http://www.academicjournals.org/article/article1379768283_Ozyigit\%20et\%20al.pdf

Parmessur, Y., Aljanabi, A., Saumtally, S., \& Dookun-Saumtally, A. (2002). Sugarcane yellow leaf virus and sugarcane yellows phytoplasma: Elimination by tissue culture. Plant Pathology, 51, 561-566. https://doi.org/10.1046/j.1365-3059.2002.00747.x

Qin, T. H., Zhou, Z. L., \& Wu, C. W. (1997). Study on the phenol pollution in tissue culture of sugarcane. Sugarcane, 4, 12-14.

Rodrigues, L. R., Tessele, C., Souza, E. A., \& Caetano, W. (2011). Preliminary assays to in vitro cloning of sugarcane accessions growing in Rio Grande do Sul state. Agrociência, 17, 01-06. Retrieved from https://periodicos.ufpel.edu.br/ojs2/index.php/CAST/article/viewFile/2025/1862

Sahijram, L., Soneji, J. R., \& Bollamma, K. T. (2003). Analyzing somaclonal variation in micropropagated banana (Musa spp.). In Vitro Cellular \& Developmental Biology_Plant, 39, 551-556. https://doi.org/ 10.1079/IVP2003467

SAS Institute Inc. (2013). Statistical Analysis System, SAS 9.4 Help and Documentation, Cary, NC: SAS Institute Inc. Retrieved from http://www.sas.com/en_us/software/sas9.html

Shimelis, D., Bantte, K., \& Feyissa, T. (2015). Effects of polyvinyl pyrrolidone and activated charcoal to control effect of phenolic oxidation on in vitro culture establishment stage of micropropagation of sugarcane (Saccharum officinarum L.). Advances in Crop Science and Technology, 3, 184. https://doi.org/10.4172/ 2329-8863.1000184

Snyman, S., Van Antwerpen, T., Ramgareeb, S., \& McFarlane, S. (2012). Sugarcane pathogens: Detection and elimination through in vitro culture. Functional Plant Science and Biotechnology, 6, 12-18. Retrieved from http:/www.globalsciencebooks.info/online/GSBOnline/images/2012/FPSB_6(SI2)/FPSB_6(SI2)12-18o.pdf

Stacklies, W., Redestig, H., Scholz, M., Walther, D., \& Selbig, J. (2007). pcaMethods-A bioconductor package providing PCA methods for incomplete data. Bioinformatics, 23, 1164-1167. https://doi.org/10.1093/ bioinformatics/btm069

Tan, L.-H., Zhang, D., Wang, G., Yu, B., Zhao, S.-P., Wang, J.-W., ... Cao, W.-G. (2016). Comparative analyses of flavonoids compositions and antioxidant activities of Hawk tea from six botanical origins. Industrial Crops and Products, 80, 123-130. https://doi.org/10.1016/j.indcrop.2015.11.035

The Statistics Portal. (2017). World sugar cane production from 1965-2014 (in million metric tones). Retrieved from http://www.statista.com/statistics/249604/sugar-cane-production-worldwide

Wolf, F. T., Tilford, R. H., \& Martinez, M. L. (1976). Effect of phenolic acid and their derivatives upon the growth of Avena coleoptiles. Zeitschrift für Pflanzenphysiologie, 80, 243-250. https://doi.org/10.1016/ S0044-328X(76)80026-8044-328X(76)80026-8 


\section{Copyrights}

Copyright for this article is retained by the author(s), with first publication rights granted to the journal.

This is an open-access article distributed under the terms and conditions of the Creative Commons Attribution license (http://creativecommons.org/licenses/by/4.0/). 